\title{
A DISTRIBUTED REAL-TIME MODEL OF DEGRADATION IN A SOLID OXIDE FUEL CELL, PART II: ANALYSIS OF FUEL CELL PERFORMANCE AND POTENTIAL FAILURES
}

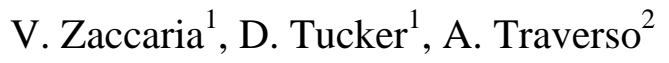

${ }^{1}$ U.S. Department of Energy, NETL, Morgantown, WV, USA

${ }^{2}$ Thermochemical Power Group, Università di Genova, Genova, Italy

* Corresponding author: 3610 Collins Ferry Rd, Morgantown, WV 26507 valentina.zaccaria@netl.doe.gov

\begin{abstract}
Solid oxide fuel cells are characterized by very high efficiency, low emissions level, and large fuel flexibility. Unfortunately, their elevated costs and relatively short lifetimes reduce the economic feasibility of these technologies at the present time. Several mechanisms contribute to degrade fuel cell performance during time, and the study of these degradation modes and potential mitigation actions is critical to ensure the durability of the fuel cell and their long-term stability. In this work, localized degradation of a solid oxide fuel cell is modeled in real-time and its effects on various cell parameters are analyzed. Profile distributions of overpotential, temperature, heat generation, and temperature gradients in the stack are investigated during degradation. Several causes of failure could occur in the fuel cell if no proper control actions are applied. A local analysis of critical parameters conducted shows where the issues are and how they could be mitigated in order to extend the life of the cell.
\end{abstract}

Keywords: SOFC, real-time model, cell degradation

\section{Nomenclature}

$F U \quad$ Fuel utilization

LSM Lanthanum - Strontium - Magnetite

PEN Positive side - Electrolyte Negative side

SOFC Solid oxide fuel cell

TPB Triple phase boundary

WGS Water gas shift

YSM Yttria-stabilized zirconia

$A_{\text {react }}$ Area of reaction $\left[\mathrm{m}^{2}\right]$

$\begin{array}{ll}F & \text { Faraday's constant }\left[\mathrm{C} \mathrm{mol}^{-1}\right] \\ G & \text { Gibbs free energy }[\mathrm{kJ}] \\ K_{p} & \text { equilibrium constant } \\ i & \text { current density }\left[\mathrm{A} \mathrm{cm}^{-2}\right] \\ i_{0} & \text { exchange current density }\left[\mathrm{A} \mathrm{cm}^{-2}\right] \\ n & \text { number of electrons transfer per } \\ & \text { reaction } \\ p & \text { partial pressure [atm }] \\ R & \text { area specific resistance }\left[\Omega \mathrm{m}^{2}\right] \\ R_{\text {oxide }} & \text { resistance of the channels }\left[\Omega \mathrm{m}^{2}\right]\end{array}$




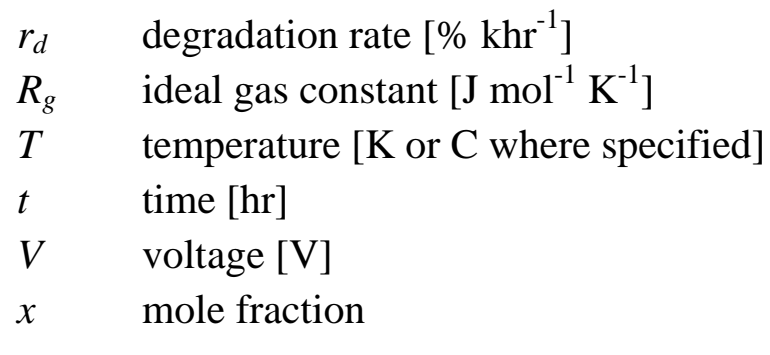

\section{Symbols}

$\alpha \quad$ charge transfer coefficient

$\Delta$ difference $\eta \quad$ electrochemical loss [V]

\section{Subscripts}

act activation

diff diffusion

irr irreversible

ohm ohmic

PEN positive side-electrolyte-negative side

\section{Introduction}

Durability of high temperature fuel cells, such as solid oxide fuel cells, is significantly impacted by diverse mechanisms of degradation, which reduce the fuel cell performance during time and can cause the failure of the stack. Many are the causes and the direct consequences of degradation mechanisms in the cell: impurities in the fuel can cause electrode poisoning delamination, coarsening of nickel particles, or carbon deposition in the anode; presence of water vapor in the cathode stream can induce materials segregation; operating conditions can cause phase separation within the anode, electrolyte cracking, or other detrimental effects [1-7]. Most of the studies present in the literature focus on the effect of fuel contaminants on cell performance degradation [8-11]. However, the direct effect of fuel cell operating parameters, such as current density and temperature, on degradation mechanisms has been observed in the literature [2, 12-18]. For this reason, a simplified, real-time model of degradation was developed in this work, where the voltage degradation rate per $1,000 \mathrm{~h}$ of operation is related to three operating parameters: current density, fuel utilization and temperature. Relating degradation to controllable parameters, rather than non-observable degradation mechanisms, allows to use control actions to mitigate degradation effects during the cell lifetime.

In Part I of this paper the real-time, one dimensional model of a SOFC with localized degradation was described and the behavior of the main parameters during degradation was shown [19]. All the details about the model and the employed empirical expression of the degradation rate were presented in Part I. In this Part II, an analysis of polarization distributions is performed. Local current density and temperature profiles, shown in the previous part, affect cell overpotential, which mainly drives degradation phenomena $[12,13]$. The paper also focuses 
on the control issues that arise when the cell degrades, in terms of performance losses, thermal management, and safe operability of the stack. Analyzing localized effects of degradation, it is possible to have a qualitative idea of what issues need to be controlled (for example, temperature gradients along the cell or heat generation distribution) when the cell is degrading, in order to develop appropriate control strategies. The cell lifetime can be predicted more accurately, since part of the cell degrades faster than others, and the necessary control actions can be evaluated. The results presented in Part I and this Part II are consistent with the ones proposed by Nakajo et al. $[12,13]$, where a very detailed model of several degradation mechanisms was employed to predict the parameters distribution along the cell and the global lifetime.

\section{SOFC model and test procedure}

The 1D, real-time model of a co-flow, planar SOFC used in this work is described in detailed in the Part I of this paper [19]. A coupled approach of finite difference and finite volume is employed to solve respectively thermal and electrochemical equations [20]. The cell is discretized in 20 volumes of calculation in the direction of fuel and air flows. Distributed profiles of all the main fuel cell parameters are calculated at each sample time of $80 \mathrm{~ms}$, which is chosen as the optimal compromize between short computational time and accuracy in capturing the transients. The constraints related to the real-time performance of the model are primarily due to its applications. As such, the SOFC model is normally coupled with hardware components of a fuel cell emulator [21]. Ongoing activities focus on the impact of cell degradation on a SOFC gas turbine hybrid system, hence the importance of ensuring short computational time while capturing the effects of local degradation [22].

Degradation rate is calculated according with Equation 1 and incorporated into the total resistance of the cell as shown in Equations 2 and 3. The algebraic expression of Eq. 1 was extrapolated from experimental data using a curve fitting approach [23]. The data set referred to experiments performed at different values of current density, fuel utilization, and temperature. Material set and fuel composition considered in this work are the same as those employed for the aforementioned experiments.

$r_{d}=\frac{0.59 F U+0.74}{1+\exp \left(\frac{T-1087}{22.92}\right)}\left(e^{264 i}-1\right)$ 
$R=\left(R_{P E N}+R_{\text {oxide }}^{\prime \prime}+R_{\text {irr }}\right) \cdot\left(1+r_{d} \cdot \frac{t}{1000}\right)$

$R_{\text {irr }}=\sum_{\text {time }}\left(R_{\text {pEN }}+R_{\text {oxide }}^{\prime \prime}\right) \times \frac{r_{d}}{1000}$

The effect of degradation is an increment in the ohmic resistance $R_{P E N}+R_{\text {oxide, }}$, which is a function of temperature. Degradation contribution is expressed in terms of the coefficient $r_{d}$ (percentage of voltage drop per 1000 hours of operation) and with the term $R_{i r}$, which represents the irreversible contribution of degradation and whose value is updated at each sample time.

Water-gas shifting (WGS) reaction is taken into account and considered at the equilibrium. The equilibrium constant for WGS reaction is presented in Equation 4. As shown in Table 1, the employed fuel is a typical coal-derived syngas containing a significant amount of hydrogen, steam, and carbon monoxide.

$K_{p, \text { shift }}=\frac{p_{H_{2}} p_{C O_{2}}}{p_{H_{2}} O p_{C O}}=\exp \left(\frac{4276}{T}-3.961\right)$

The operating parameters considered for this test are reported in Table 1.

\begin{tabular}{|l|l|}
\hline Cathode air flow & $1.00 \mathrm{~kg} / \mathrm{s}$ \\
\hline Cathode inlet temperature & $690^{\circ} \mathrm{C}$ \\
\hline Cathode inlet pressure & $0 \mathrm{kPag}(1 \mathrm{~atm})$ \\
\hline Current & $200 \mathrm{~A}$ \\
\hline Fuel flow & $0.095 \mathrm{~kg} / \mathrm{s}$ \\
\hline Fuel utilization & $80 \%$ \\
\hline Average cell temperature & $820^{\circ} \mathrm{C}$ \\
\hline Anode inlet temperature & $800^{\circ} \mathrm{C}$ \\
\hline Fuel composition & $29.1 \% \mathrm{H}_{2}, 27.1 \% \mathrm{H}_{2} \mathrm{O}, 28.6 \% \mathrm{CO}$, \\
& $12 \% \mathrm{CO}_{2}, 3.2 \% \mathrm{~N}_{2}$ \\
\hline
\end{tabular}

Table 1. Nominal operating conditions

Target current, airflow and fuel flow were kept constant during the simulation and equal to their nominal value, letting the cell power degrade. An analysis of the results for 12,000 hours of operation are presented in the following section. The model was run to reach steady state conditions and then the degradation was applied to the cell. In the following charts, the "time $=0$ " is the moment when the degradation started, i.e. it shows the steady state profiles before the cell starts degrading. Although the experimental data used to extrapolate the degradation rate expression were collected for less than 3,000 hours of operation, the following results can give a 
qualitative idea of the trends. Considering the limited collection period of data used to develop the degradation model, quantitative uncertainty exists for extended operating times over 10,000 hours.

\section{Results and discussion}

An analysis of key operating parameters behavior during cell degradation was the object of Part I of this paper [19] and is summarized here. With the chosen syngas composition, at the beginning of the cell life, current density is higher at the cell inlet, following the hydrogen concentration. Solid temperature is lower at the inlet and follows a non-linear trend along the cell. These factors contribute to induce a high degradation rate at the inlet, presented in Figure 1, and consequently degrade the first part of the cell faster. Resistance increases at the inlet, shifting the current density peak towards the outlet, which causes a reduction in solid temperature at the inlet and an increment at the outlet. The high temperature in the second half of the cell reduces the total resistance, allowing the local current density to increase at the cell outlet. This results in a fairly uniform distribution of the degradation rate along the cell after 6,000 hours.

\section{$\underline{3.1 \text { Nernst potential }}$}

Nernst potential is calculated according with Equation 6, assuming that hydrogen is the only species that is directly oxidized. The water-gas shift reactions are considered fast enough to be at equilibrium and to neglect the effect of direct electrochemical CO oxidation on the cell [24-26].

$V_{\text {NERNST }}=-\frac{\Delta G_{H_{2} O}^{0} O}{n F}+\frac{R_{u} T}{n F} \ln \left(\frac{p_{H_{2}} \sqrt{p_{O_{z}}}}{p_{H_{2} O} \mathrm{O}}\right)$

Nernst potential is higher for lower temperature and higher $\mathrm{H}_{2}$ partial pressure. At the beginning of the cell life, its profile mainly follows the hydrogen mole fraction distribution, which is directly proportional to $\mathrm{H}_{2}$ partial pressure. As the cell degrades, in the first nodes the temperature decreases and hydrogen partial pressure shows an increment because of the reduction in current density, and consequently Nernst potential increases. The shape of the curve changes with time primarily with hydrogen partial pressure, i.e. hydrogen concentration. In the last two nodes Nernst decreases after $500 \mathrm{~h}$, consistently with the increment of temperature. The profiles at different times are shown in Figure 2.

\section{$\underline{3.2 \text { Overpotential }}$}


Ohmic losses are presented in Equation 7. Degradation directly affects the ohmic overpotential through the term $R$, as previously shown in Equations 2 and 3.

$\eta_{o h m}=R \cdot i$

Ohmic losses profile during time depends on the behaviors of total resistance, which increases at the cell inlet due to a reduction in temperature and the effect of degradation, and local current density, whose peak shifts from the inlet to the outlet as the cell degrades. For this reason the ohmic losses increase significantly in the first part of the cell (an order of magnitude after 12,000 h), but also in the last part where the resistance is lower but the current density is higher. Their trend is shown in Figure 3. After 2,000 h ohmic losses represent the main contribution to the lost term.

Butler-Volmer equation is used to calculate activation overpotential, as illustrated in Equation 8.

$\eta_{\text {act }}=\frac{R_{g} T}{\alpha n F} \sinh ^{-1}\left(\frac{i}{2 i_{0}}\right)$

Activation losses are lower when the temperature is higher, and they depend directly on current density. In the first part of the cell, activation losses decrease with time because of the significant reduction in current density, while in the last part of the cell losses increase because of the increment in local current density but are limited by increasing temperatures, as shown in Figure 4a. After 6,000 h activation losses are fairly uniform along the cell. A first peak is always in the first node, where the temperature is lower. At 12,000 h they show a second peak at the outlet corresponding to the peak in current density. A local minimum can be seen around node 9, caused by the double effect of very low current density and fairly high temperature.

Diffusion losses are calculated according with Equation 9, and their trend is presented in Figure 4b. The bulk concentrations are the ones at the fuel and air streams, while the concentration at the TPB are reduced of a factor function of the diffusion coefficients [20].

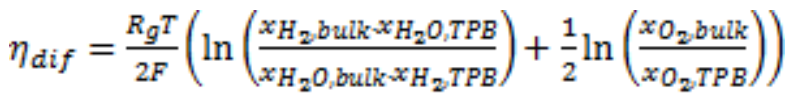

Regarding the diffusion losses, a decrement is observed in the first part of the cell and a significant increment is seen in the last nodes. This is consistent with the increased current density and lower hydrogen content at the end of the cell. The magnitude of diffusion losses is 
much lower compared with ohmic and activation polarizations, so they do not affect net voltage significantly.

\section{$\underline{3.3 \text { Cell voltage }}$}

Cell voltage is calculated from the ideal Nernst potential, from which the lost terms are subtracted, as Equation 10 shows.

$V_{\text {cell }}=V_{\text {NERNST }}-\eta_{\text {dif }}-\eta_{\text {act }}-\eta_{\text {ohm }}$

Voltage trend is shown in Figure 5 with the global degradation rate. Voltage reduces around 12\% in $12,000 \mathrm{~h}$. The first $100 \mathrm{~h}$ in the charts represent the steady state, when degradation is not yet applied to the cell (degradation rate is zero). Then the degradation rate increases sharply during the first hours, and consequently the voltage presents a sudden decrement around $0.9 \%$. Then

degradation rate starts decreasing slowly, because the average solid temperature increases, and the localized distribution of current and temperature mitigate cell degradation. For this reason, voltage negative slope is lower in absolute terms as time proceeds. In the Figure, two zones are highlighted, before and after a time close to 6,000 h. In the first part, the degradation rate is clearly decreasing with time, while in the second one the rate is not changing much, resulting in a quasi-linear trend of voltage.

\subsection{Heat generation, heat transfer, and temperatures}

Both the reactions of water-gas shift and water formation are exothermic and heat is generated from the reactions. The profile of generated heat mainly follows the hydrogen consumption i.e. the current density trend with time, as shown in Figure 6a, with the exception of the first node where even if the current density decreases significantly a certain amount of heat is generated by the shift reactions. The heat generation trend during time presents an issue in terms of thermal management of the cell. At the beginning of life, more heat is generated in the first part of the cell, which can be easily cooled down by the air flow, since air temperature is low. After 2,000 hours of operation the peak in heat generation is located in the end of the cell, where the heat transfer between solid and air flow is approximately one forth than at the cell inlet, because the air temperature is higher, as Figure 6b illustrates. 
The total generated heat increases with time (56 kW in 12,000 hours), consistently with the reduction in power and efficiency due to cell degradation.

Heat generation mainly drives the solid temperature profile. The $\Delta \mathrm{T}$ between solid and air determines the heat flux from solid to gas. As degradation occurs, the generated heat decreases in the first part of the cell due to decreased current density, followed by a reduction in solid temperature. The change in solid temperature profile primarily drives the change in heat flux from solid to air, which decreases in the first part of the cell due to a lower $\Delta \mathrm{T}$ between solid and air and increases in the second half for the opposite reason. The trends of generated heat and transferred heat could be problematic, because as degradation continues, the heat transfer at the end of the cell increases only about $230 \%$, while the generated heat presents an increment of about $460 \%$. This causes the solid temperature to increase, and contributes to its non-linear profile, resulting in more severe temperature gradients within the cell, as shown in Figure 7. More airflow is intuitively a potential solution, but this may cause more cooling in the beginning of the cell, which is generating less heat over time.

The temperature gradient in the solid structure shows a trend similar to the current density, as Figure 7 illustrates, because where more current is generated solid temperature increases faster. However the peak in thermal gradient is not located at the same node that current density peak, because temperature dynamics are slower. At time 0 the peak is in the first part of the cell, but as time proceeds it is shifted towards the center and increases significantly. As the temperature profile showed a sigmoidal trend, the maximum temperature gradient is expected to be located in the middle of the cell as degradation proceeds.

The trends show that, as the cell is degrading, the gradients could reach unacceptable values if no control action is applied. These gradients can bring the cell to a catastrophic failure, as the ceramic electrolyte is very sensitive to thermal stresses. As a matter of fact, it has been posed that temperature gradient represents the largest contribution to thermal stress in the electrolyte $[27,28]$. For this reason, this issue must be addressed with appropriate airflow management.

\section{$\underline{4.8 \text { Temperature difference and thermal effluent }}$}

Cathode inlet temperature is held constant with time, while outlet air temperature increases due to the increment in heat transfer from solid to gas. Consequently, temperature difference between 
cell outlet and inlet increases with time. This means that more heat was transferred from solid to the air, i.e. cathode airflow was cooling the cell. The total thermal effluent to the air increases. Total thermal effluent is defined as the enthalpy difference between cathode inlet airflow and the hot gases at the exit of the off-gas burner, as Equation 11 shows.

$\dot{Q}=h_{\text {out }}-h_{\text {in }}$

Both temperature difference and thermal effluent are presented in Figure 8, where it is possible to see that they follow the same trend with time. The total thermal effluent comprises also the heat generated in the off-gas burner downstream the fuel cell, but since the fuel utilization, and hence the amount of unutilized fuel, is constant, its variation depends only on $\Delta \mathrm{T}$ changes.

The increment in thermal effluent is driven mainly by the $55 \mathrm{~kW}$ increase in heat generation in the fuel cell, and it reflects the reduction in electric power (about $55 \mathrm{~kW}$ as well), also shown in Figure 8. Cell electric power follows the same trend as voltage during time.

\section{Conclusion}

The analysis of the profiles of several fuel cell parameters during cell degradation was carried out with a real-time, distributed model. Degradation was taken into account as an increment in ohmic resistance, as a function of the following operating parameters: current density, fuel utilization, and temperature. The fuel cell is fed with syngas and operates at constant current, airflow and fuel flow for $12,000 \mathrm{~h}$. The cell degrades immediately at the inlet, where current density and fuel utilization are higher, and temperature is lower. The localized degradation is considered related to the overpotential distribution at the beginning of life, which is higher in the first part of the cell. This increases the resistance at the inlet, shifting the current density peak toward the center of the cell. After 500 hours, cell parameters such as current density, electrochemical losses and heat generation are higher in the center of the cell. After 2,000 h, overpotential and heat generation show a peak at the outlet of the cell, which increases significantly with time. Activation and diffusion losses decrease at the inlet part and increase at the outlet, while ohmic losses significantly increase everywhere. The cell voltage present a $12 \%$ reduction after $12,000 \mathrm{~h}$ of operation and the total thermal effluent to the air increases by about $15 \%$. 
Although average cell temperature is fairly constant during time, temperature gradients show an increment during time, which could bring the cell to failure in the long term if no mitigation action is applied. Temperature difference between inlet and outlet starts at $170^{\circ} \mathrm{C}$, but reaches $230^{\circ} \mathrm{C}$ after $12,000 \mathrm{~h}$. These aspects certainly impact on control strategy development. In particular, for the thermal management of the cell, the evolution of heat generation profile needs to be taken into account. After 2,000 h the peak in generated heat is located at the end of the cell, where the air temperature is higher and hence the air cooling effect is reduced. Even if the heat transfer between solid and air increases with time in the last part of the cell, the value is still four times lower than in the first half of the cell after $12,000 \mathrm{~h}$.

Future investigations will consider the application of controllers to maintain power and fuel utilization constant while the cell is degrading, and to mitigate temperature gradients.

\section{Acknowledgment}

This work was funded by the U.S. Department of Energy (DOE) Crosscutting Research Program of the National Energy Technology Laboratory (NETL). The authors would like to thank Dr. Paolo Pezzini from Ames Laboratory (IA), Dr. Nor Farida Harun from McMaster University (Canada) and Dr. Kirk Gerdes from NETL.

\section{References}

[1] D.E. Vladikova, Z.B. Stoynov, A. Barbucci, M. Viviani, Impedance Studies of Cathode/Electrolyte Behavior in SOFC, Electrochimica Acta 53 (2008) 7491-7499.

[2] G.J. Offer, N.P. Brandon, The Effect of Current Density and Temperature on the Degradation of Nickel Cermet Electrodes by Carbon Monoxide in Solid Oxide Fuel Cells, Chemical Engineering Science 64 (2009) 2291-2300.

[3] G. Hackett, 2009, Interaction of Nickel-based SOFC Anodes with Trace Contaminants from Coal-derived Synthesis Gas, $\mathrm{PhD}$ Dissertation, College of Engineering and Mineral Resources at West Virginia University, Morgantown, WV.

[4] R.R. Liu, S.H. Kim, S. Taniguchi, T. Oshima, Y. Shiratori, K. Ito, K. Sasaki, Influence of water vapor on long-term performance and accelerated degradation of solid oxide fuel cell cathodes, Journal of Power Sources 196 (2011) 7090-7096. 
[5] A.C.Mueller, A.Weber, D. Herbstritt, E. Ivers-Tiffee, in: S.C. Singhal, M. Dokiya (Eds.), Proceedings of the Eighth International Symposium on Solid Oxide Fuel Cells (SOFCVIII), PV 2003-07, The Electrochemical Society, Pennington, NJ, 2003, pp. 196-199.

[6] D. Skarmoutsos, F. Tietz, P. Nikolopoulos, Structure - property relationship of Ni/YSZ and $\mathrm{Ni} /\left(\mathrm{YSZ}+\mathrm{TiO}_{2}\right)$ Cermets, Fuel Cells 1 (2001) 243-248, DOI: 10.1002/16156854(200112)1:3.

[7] H. Yokokawa, T. Watanabe, A. Ueno, K. Hoshino, Investigation on Degradation in Long-Term Operations of Four Different Stacks/Modules, ECS Trans. 7 (1) (2007) 133140.

[8] H. Yokokawa, T. Horita, N. Sakai, J. Yamaji, M.E. Brito, Y.P. Xiong, H. Kishimoto, Thermodynamic considerations on Cr poisoning in SOFC cathodes, Solid State Ionics, 177 (2006) 3193-3198, doi:10.1016/j.ssi.2006.07.055.

[9] H. Yokokawa, H. Sakai, T. Horita, K. Yamaji, M.E. Brito, H. Kishimoto, Thermodynamic and kinetic considerations on degradations in solid oxide fuel cell cathodes, J. Alloy Compd., 452 (2008) 41-47, doi:10.1016/j.jallcom.2006.12.150.

[10] J. Bao, G.N. Krishnan, P. Jayaweera, J. Perez-Mariano, A. Sanjurjo, Effect of various coal contaminants on the performance of solid oxide fuel cells: Part I. Accelerated testing, J. Power Sources, 193 (2009), pp. 607-616, doi:10.1016/j.jpowsour.2009.04.034.

[11] J. Bao, G.N. Krishnan, P. Jayaweera, K.H. Kau, A. Sanjurjo, Effect of various coal contaminants on the performance of solid oxide fuel cells: Part II. ppm and sub-ppm level testing, J. Power Sources, 193 (2009), pp. 617-624, doi:10.1016/j.jpowsour.2009.04.035.

[12] A. Nakajo, F. Mueller, J. Brouwer, J. van Herle, D. Favrat, Progressive activation of degradation processes in solid oxide fuel cells stacks: Part I: Lifetime extension by optimisation of the operating conditions, Journal of Power Sources 216 (2012) 449-463, DOI:10.1016/j.jpowsour.2012.05.078.

[13] A. Nakajo, F. Mueller, J. Brouwer, J. van Herle, D. Favrat, Progressive activation of degradation processes in solid oxide fuel cells stacks: Part II: Spatial distribution of the degradation, Journal of Power Sources 216 (2012) 434-448, DOI: 10.1016/j.jpowsour.2012.05.077.

[14] T. Iwata, Characterization of Ni-YSZ Anode Degradation for Substrate-Type Solid Oxide Fuel Cells, J. Electrochem. Soc. 143 (5) (1996) 1521-1525, DOI: 10.1149/1.1836673.

[15] A. Hagen, R. Barfod, P.V. Hendriksen, Degradation of Anode Supported SOFCs as a Function of Temperature and Current Load, J. of Electrochem. Soc., 153 (2006) A1165A1171. 
[16] A. Hagen, Y.L. Liu, R. Barfod, P.V. Hendriksen, Assessment of the Cathode Contribution to the Degradation of Anode-Supported Solid Oxide Fuel Cells, J. of Electrochem. Soc., 155 (2008) B1047-B1052.

[17] S. Koch, P. Hendriksen, M. Mogensen, Y. Liu, N. Dekker, B. Rietveld, B. de Haart, F. Tietz, Solid Oxide Fuel Cell Performance under Severe Operating Conditions, Fuel Cell, 6 (2006) 130-136, DOI: 10.1002/fuce.200500112.

[18] L. de Haart, J. Mougin, O. Posdziech, J. Kiviaho, N. Menzler, Stack Degradation in Dependence of Operation Parameters; the Real-SOFC Sensitivity Analysis, Fuel Cell, Vol. 9, Issue 6 (2009) 794-804, DOI: 10.1002/fuce.200800146.

[19] V. Zaccaria, D. Tucker. A. Traverso, A distributed real-time model of degradation in a solid oxide fuel cell, Part I: Model Characterization, Journal of Power Sources.

[20] D. Hughes, W.J. Wepfer, K. Davies, C. Haynes, D. Tucker, A Real-time Spatial SOFC Model for Hardware-Based Simulation of Hybrid Systems, International ASME Conference on Fuel Cell Science, Engineering and Technology 2011.

[21] D. Tucker, M. Shelton, A. Manivannan, The Role of Solid Oxide Fuel Cells in Advanced Hybrid Power Systems of the Future, Interface (2009) 25-28.

[22] V. Zaccaria, D. Tucker, A. Traverso, Control Strategies to Minimize Degradation in Fuel Cell Gas Turbine Hybrids, Proceedings of $6^{\text {th }}$ European Fuel Cell - Piero Lunghi Conference 2015, Naples, Italy, Paper Number EFC15009.

[23] V. Zaccaria, D. Tucker, A. Traverso, A Real-time Degradation Model for Hardware in the Loop Simulation of Fuel Cell Gas Turbine Hybrid Systems, Proceedings of ASME Turbo Expo 2015, Montreal, Canada, Paper number GT2015-43604.

[24] M. Li, J. Brouwer, J.D. Powers, G.S. Samuelsen, A Finite Volume SOFC Model For Coal-Based Integrated Gasification Fuel Cell System Analysis, in ASME 7th International Fuel Cell Science, Engineering and Technology Conference, ASME, Editor. 2009, ASME: Newport Beach, CA.

[25] P. Aguiar, C.S. Adjiman, N.P. Brandon, Anode-Supported Intermediate Temperature Direct Internal Reforming Solid Oxide Fuel Cell. I: Model-Based Steady-State Performance, Journal of Power Sources 138 (2004) 120-136, doi:10.1016/j.jpowsour.2004.06.040.

[26] H. Yakabe, T. Ogiwara, M. Hishinuma, I. Yasuda, 3D Model Calculation for Planar SOFC, Journal of Power Sources 102 (2001) 144-154, DOI: 10.1016/S03787753(01)00792-3. 
[27] S.C. Singhal, K. Kendall, Cell, Stack and System Modeling, in: S.C. Singhal, K. Kendall, High Temperature Solid Oxide Fuel Cells: Fundamentals, Design, and Applications, Elsevier, Oxford, 2003, pp. 291-332.

[28] E. Ivers-Tiffée, A. Weber, D. Herbstritt, Materials and technologies for SOFCcomponents, J. Eur. Ceram. Soc. 21 (2001) 1805-1811. 


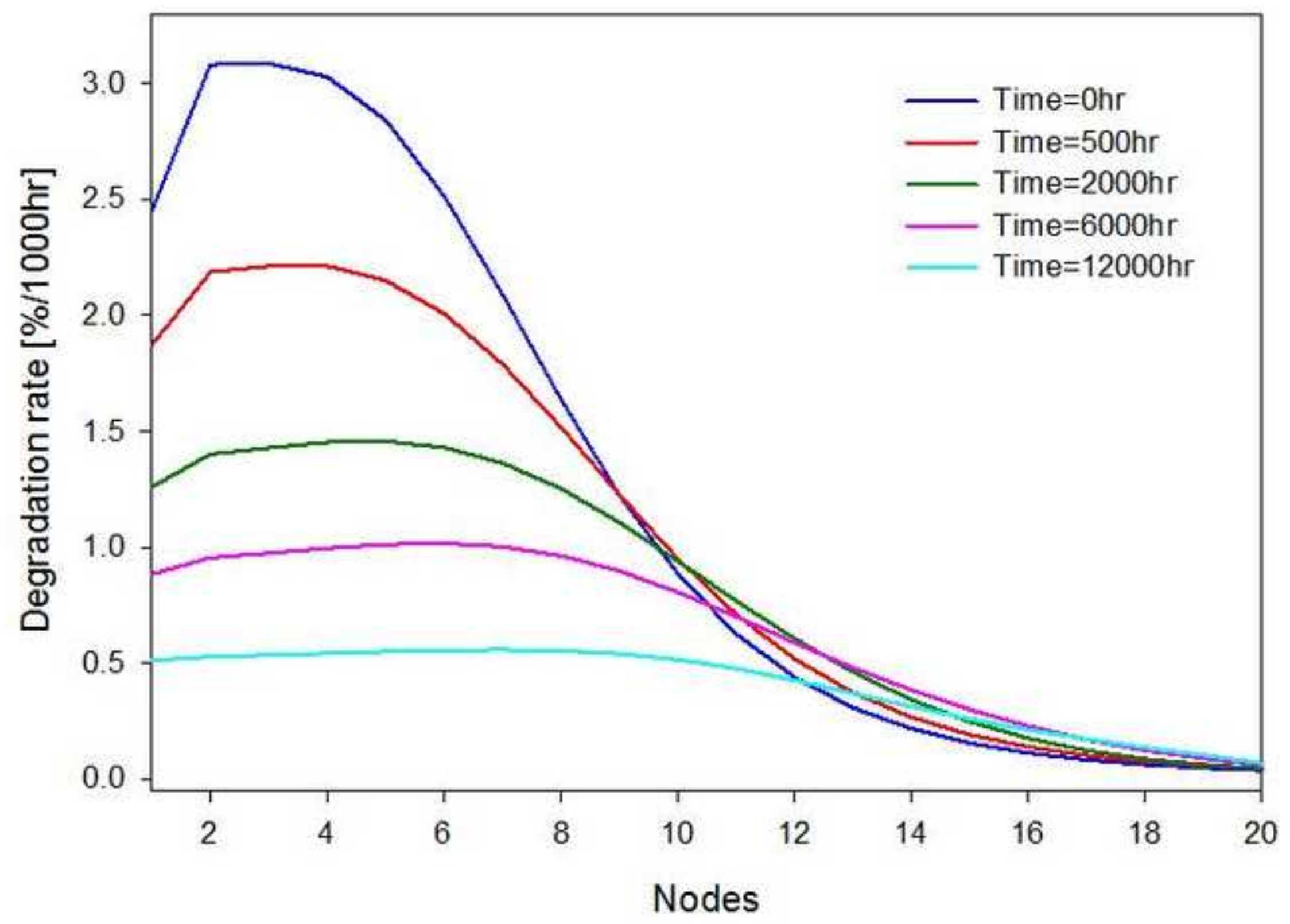




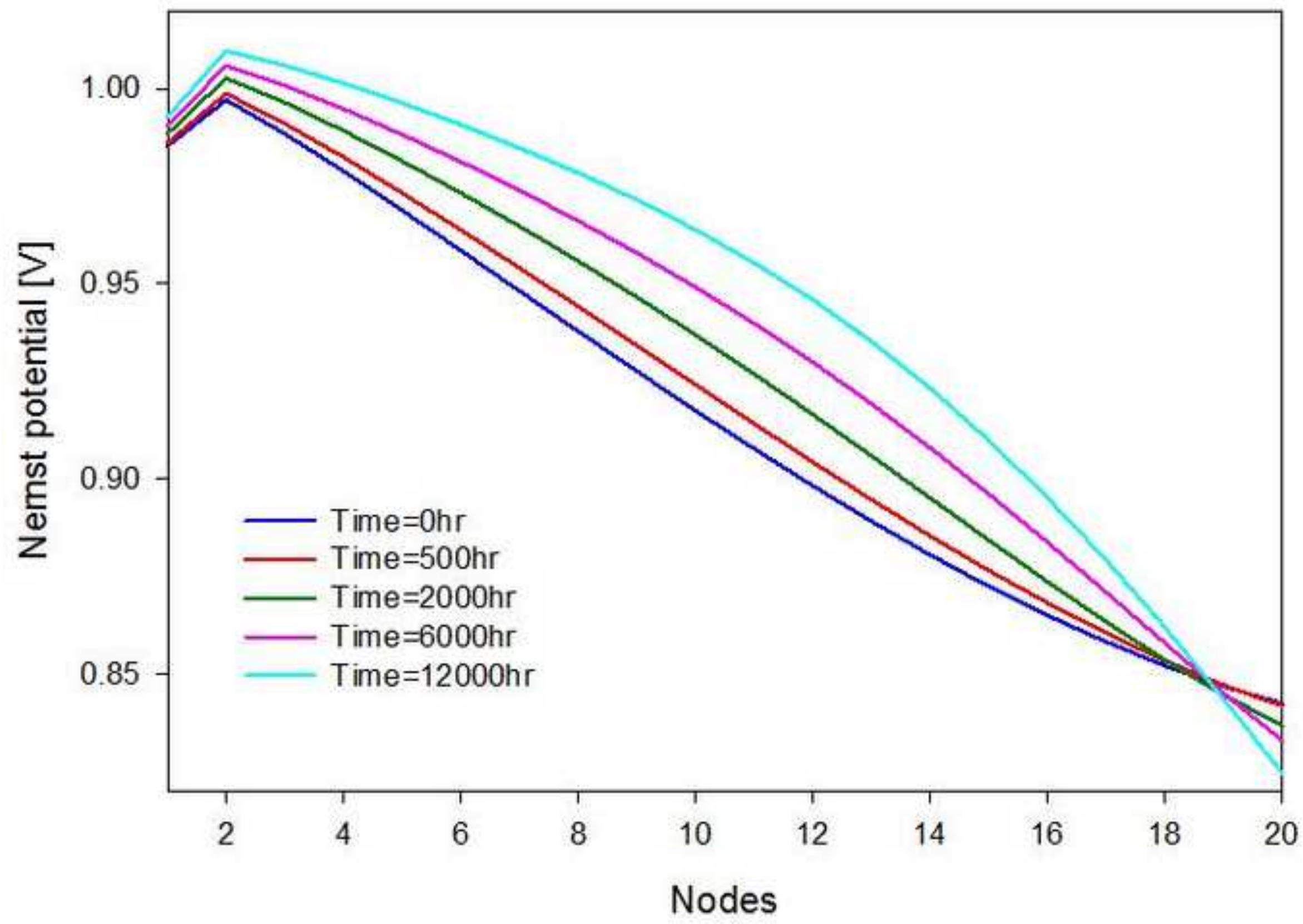




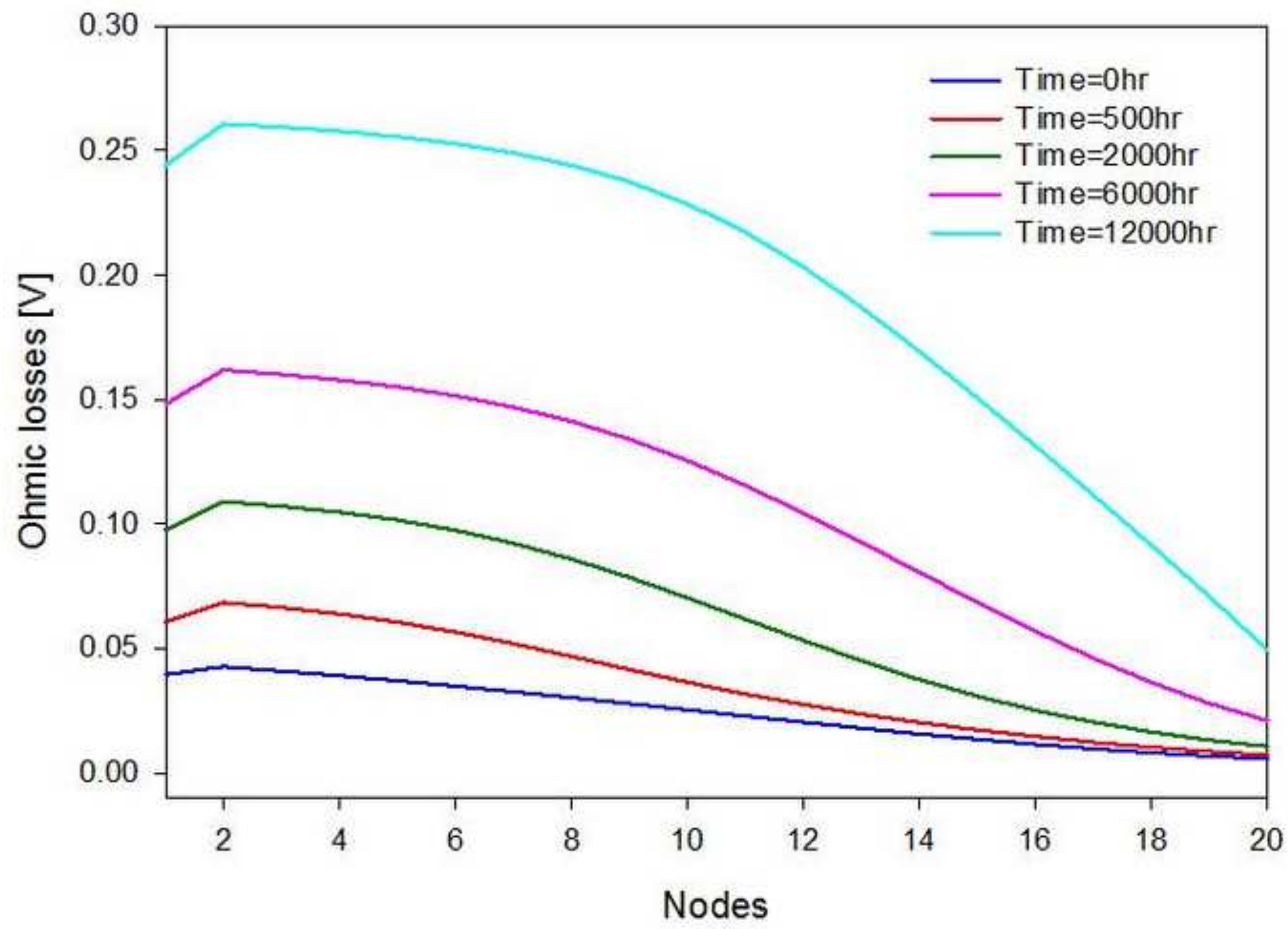




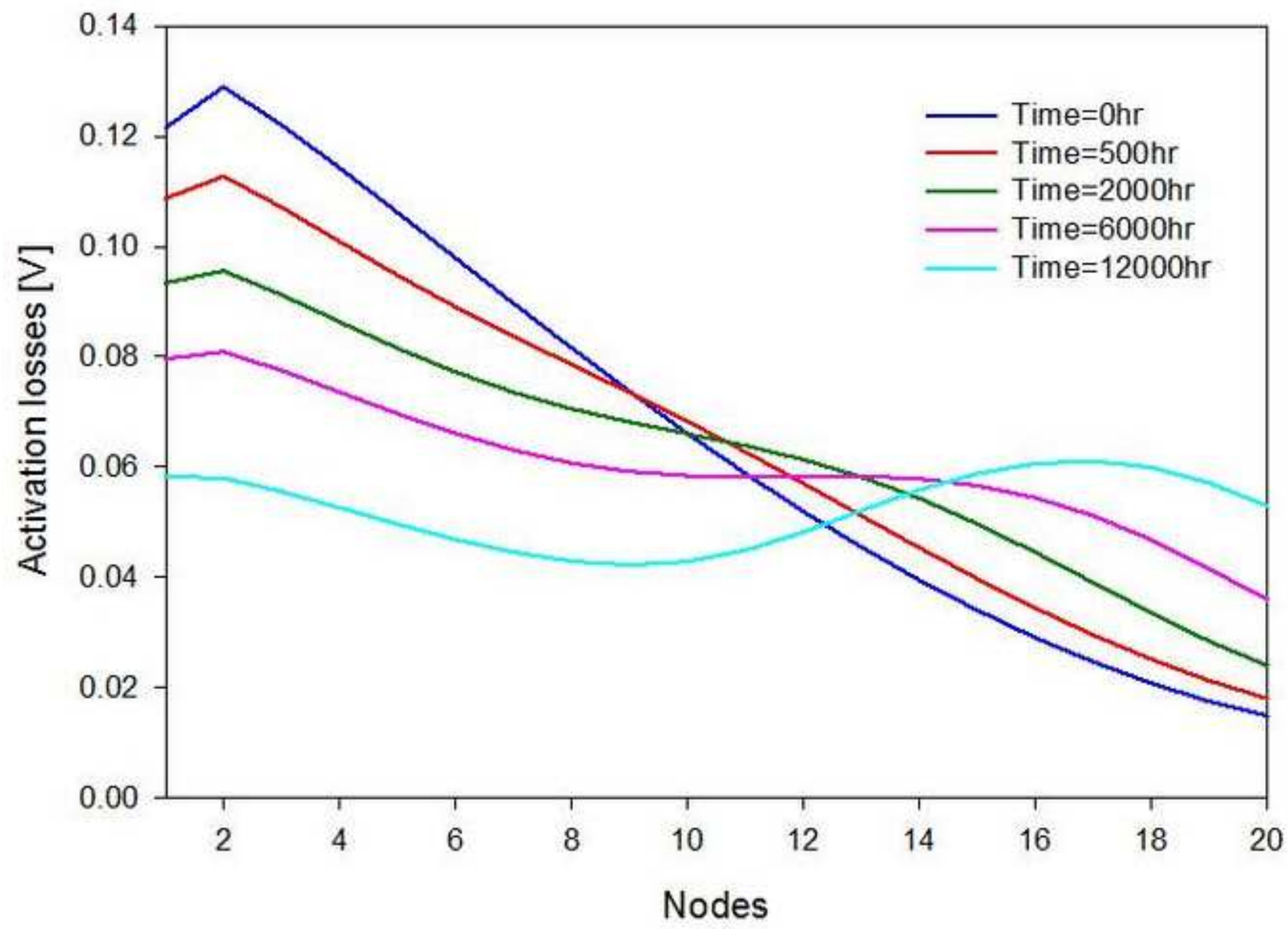




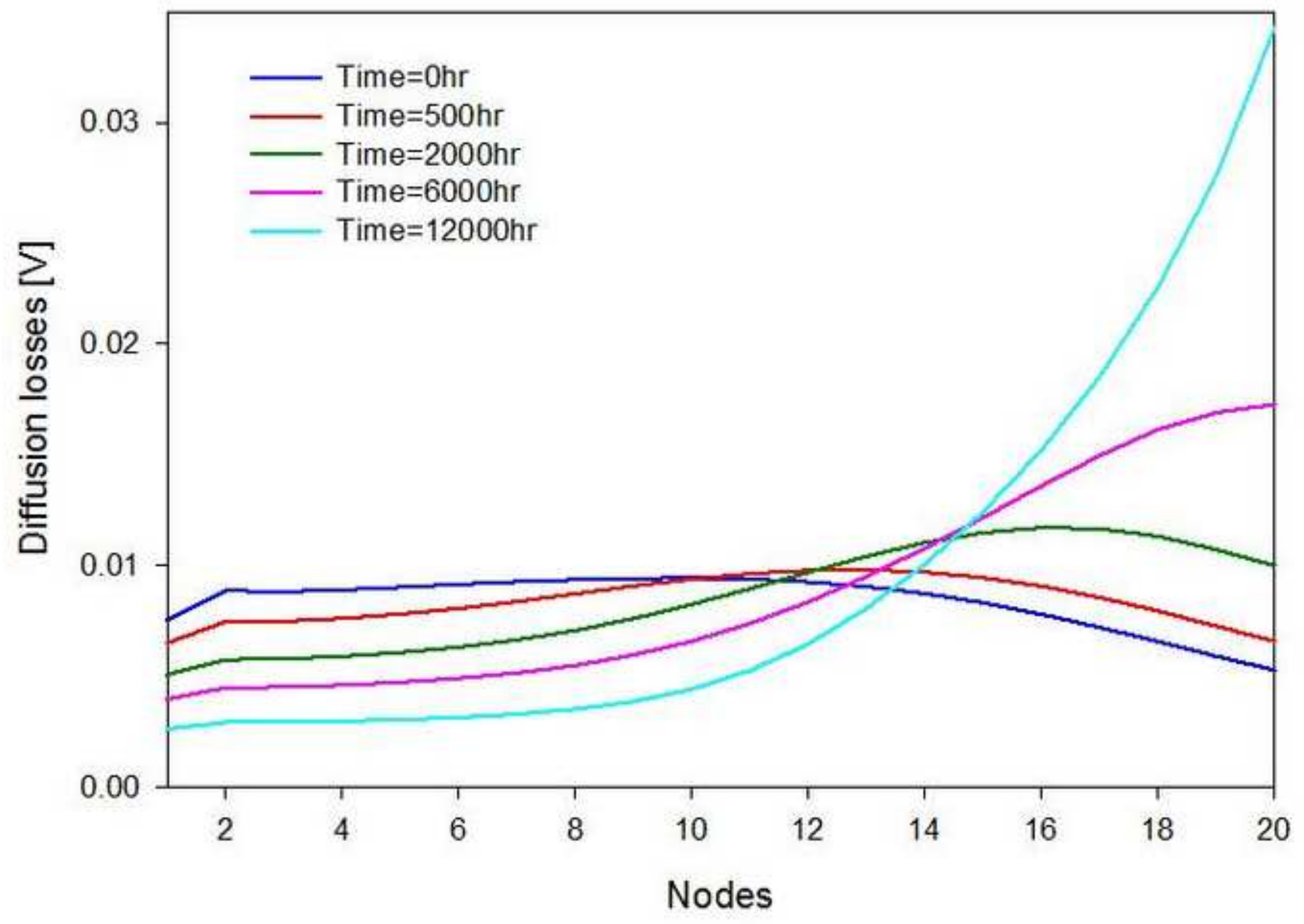




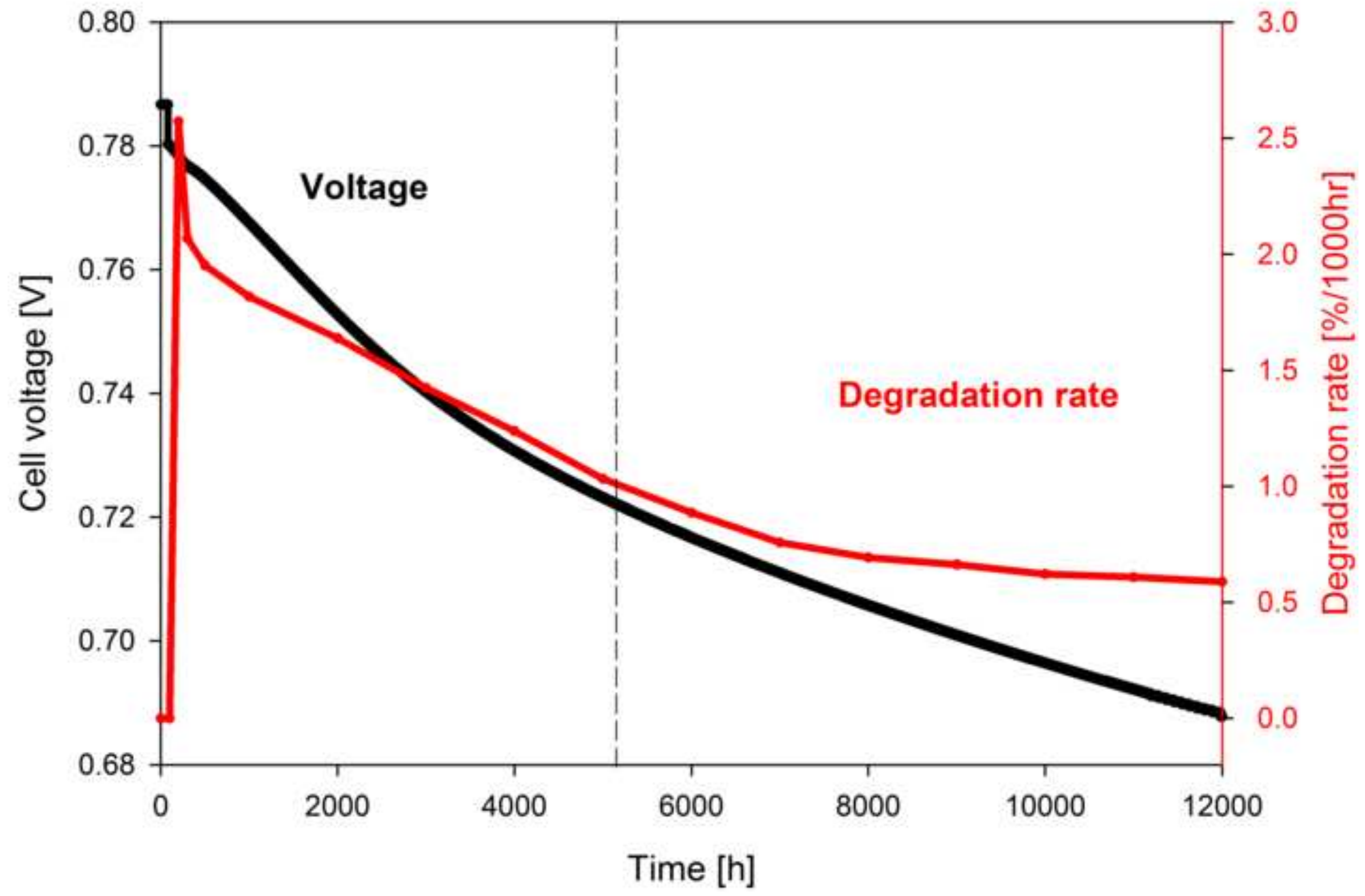




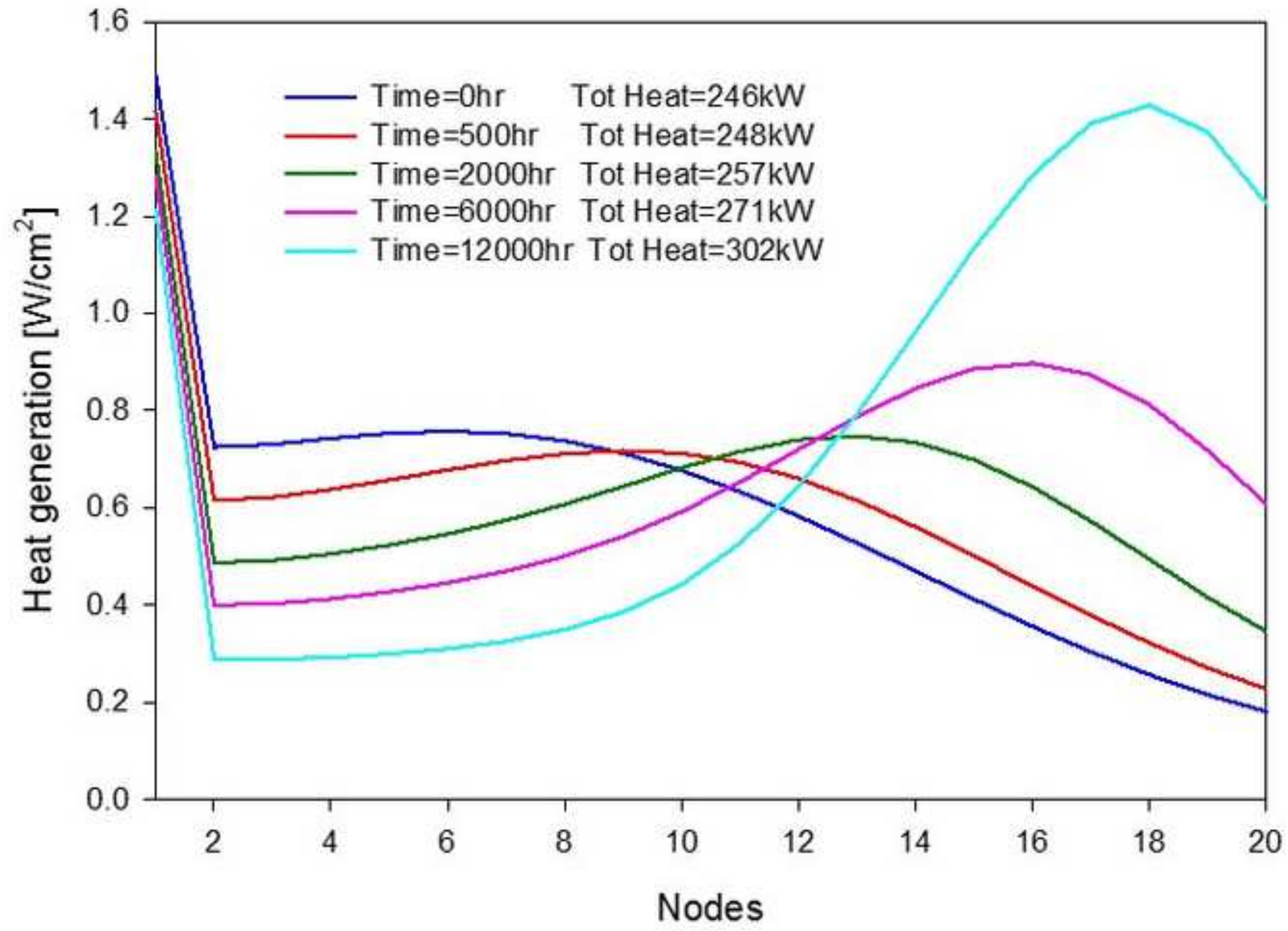




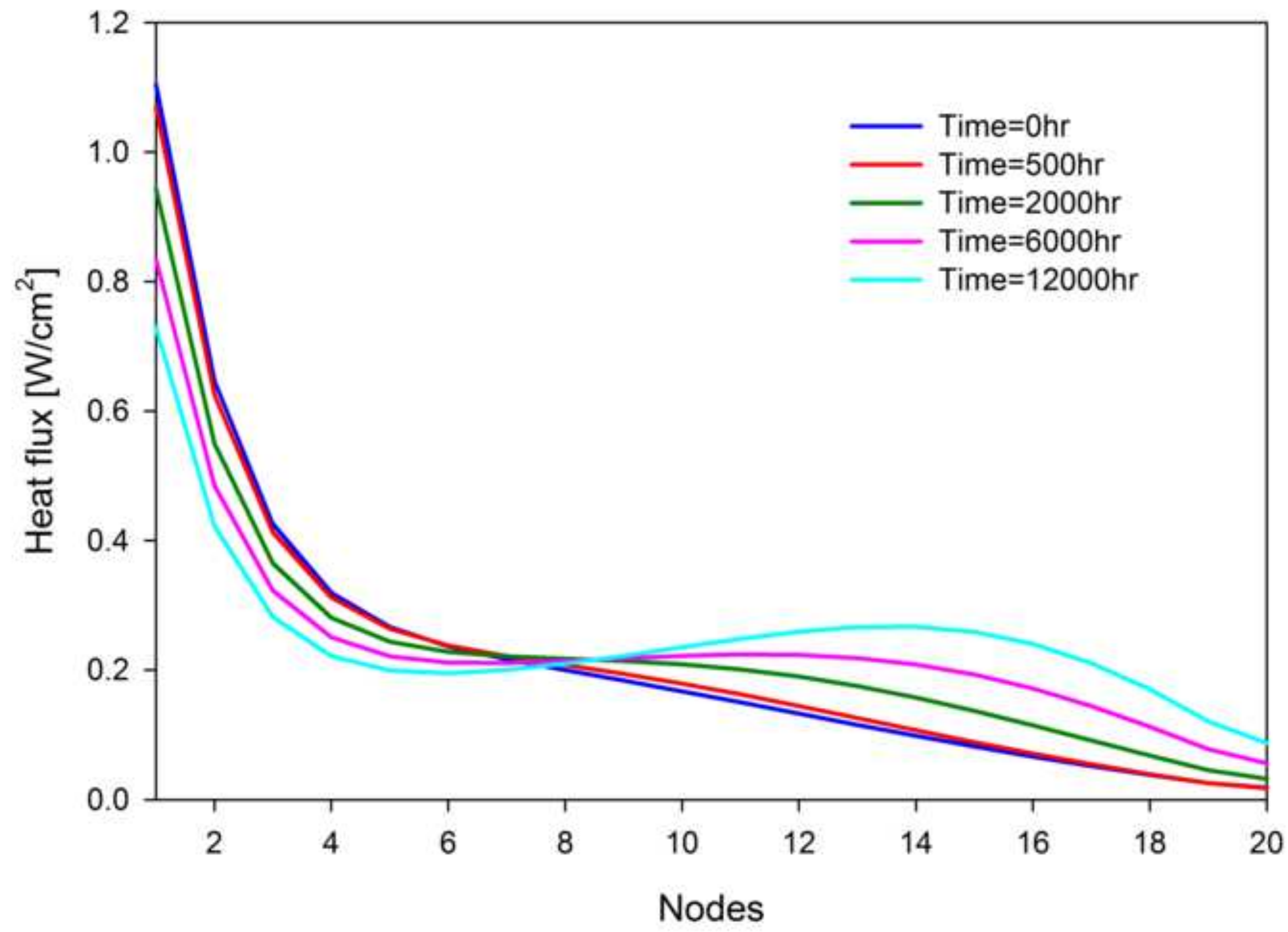




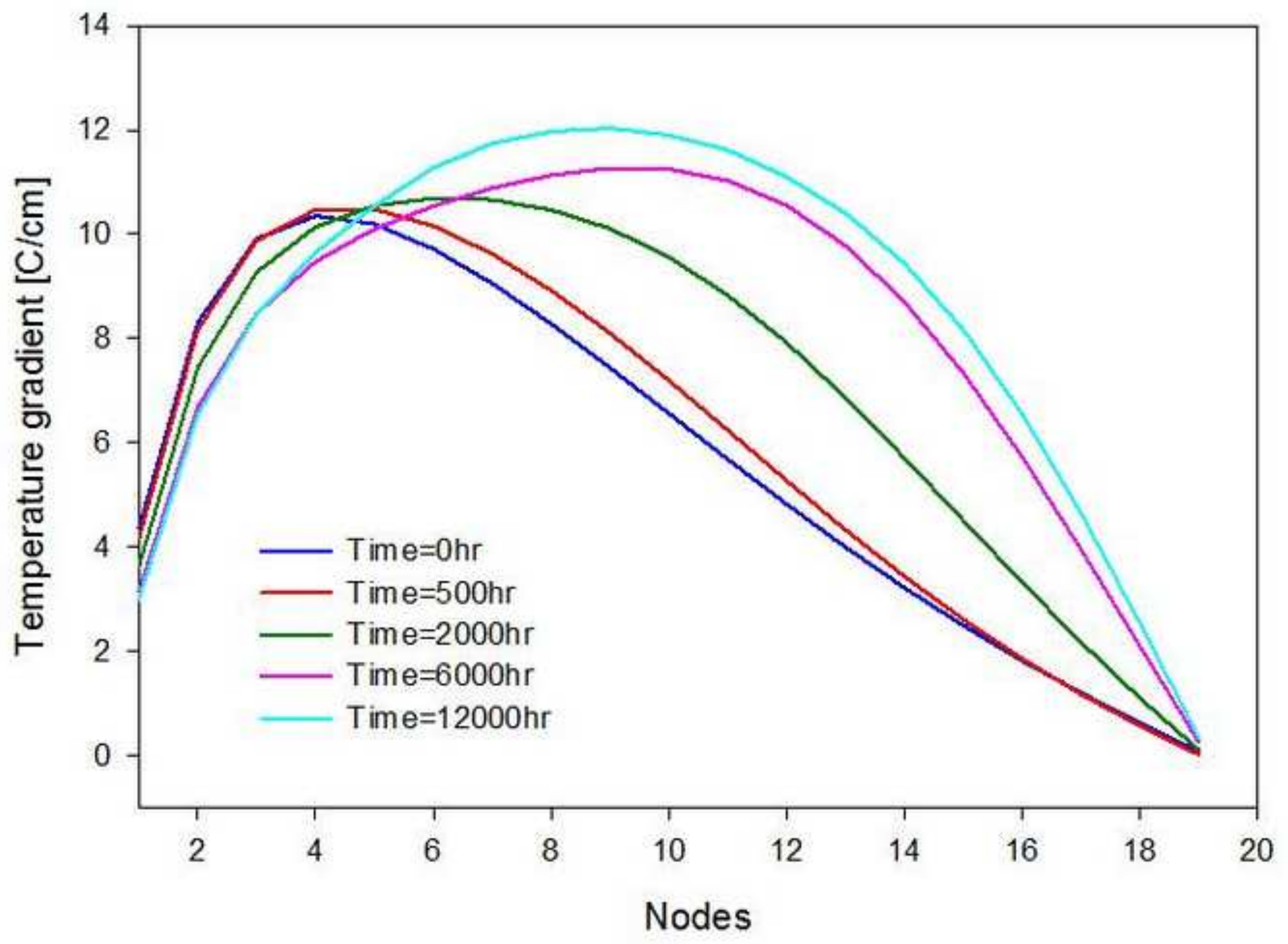




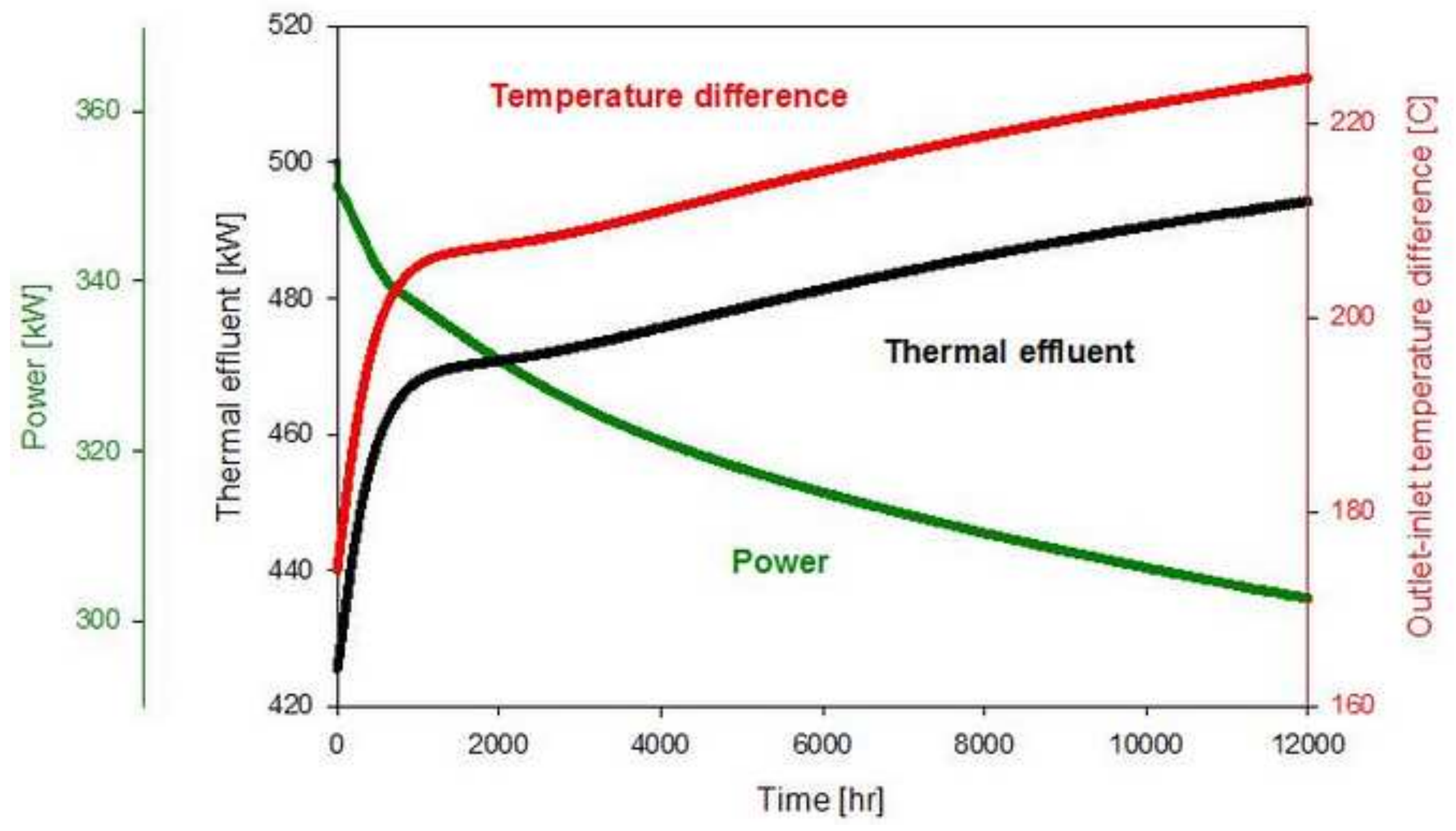




\section{Figures caption}

Fig. 1 Degradation rate profiles along the cell at different time

Fig. 2 Nernst potential profiles along the cell at different time

Fig. 3 Ohmic losses profiles along the cell at different time

Fig. 4a Activation losses profiles along the cell at different time

Fig. 4b Diffusion losses profiles along the cell at different time

Fig. 5 Cell voltage and global degradation trends

Fig. 6a Heat generation profiles along the cell at different time

Fig. 6b Heat transfer between solid and gas profiles along the cell at different time

Fig. 7 Temperature gradient profiles in the solid structure at different time

Fig. 8 Air temperature difference, thermal effluent and cell power trends 